\title{
Correspondence
}

\section{Prescription charges}

DeAR SIR,

It is gratifying to note the continued concern of the College over the problems arising from the current exemptions from prescription charges. ${ }^{1}$ We feel, however, that the question of hardship is incidental to the main issue. It is extremely difficult for the psychiatrist to assess actual hardship, which, to be objective, would require the patient to be means-tested. Patients hardly ever complain, and psychiatric patients seem to do so less than most. In any case, this particular aspect of the exemption rules has already been taken up by the Royal College of General Practitioners and by the Pharmaceutical Society. ${ }^{2}$

What appears to us to be the most important point to make is the fact that current rules unfairly discriminate against chronic psychiatric patients who require maintenance medication. CHC's have been aware of this problem, ${ }^{3}$ and last September the Association of CHC's for England and Wales almost unanimously recommended an approach to the DHSS to argue this case. The College's support on this matter would surely add considerable weight to their representations.

Netherne Hospital

Coulsdon, Surrey CR3 IYE

REFERENCES

1 Bulletin, June 1980, p. 99.

${ }^{2}$ Medical News, April 1980, p. 1.

${ }^{3}$ CHC News, May 1980, p. 1.

\section{DeAR SIR, \\ Recruitment to mental handicap work}

While agreeing with Drs Hauck (July, 1980, p. 108) and Cooper (September, 1980, p. 144) that a three-month rotational period in mental handicap is too short a time to learn the many facets of this interesting sub-specialty, this type of rotation does at least enable a number of psychiatrists to gain exposure and some experience in the subject.

The first three years of a three-year rotational scheme here enabled three registrars to work in mental handicap each year, giving them each a four month block. Of those involved, four have gone on to get senior posts in this discipline (which was approximately half of all those taking part in the scheme). The difficulty presented by a much longer block of training in mental handicap is that not all those psychiatrists taking part are likely to be of suitable temperament, and if they have to stay in a hospital or community service for the mentally handicapped for a prolonged period, this does not benefit their training or the service itself. I would recommend that a compromise period of four to six months should be adopted.

\section{Earls House Hospital,}

MARION WAY Durham, DHI SRE.

DeAR SIR,

I fully support the views of Drs Fowlie and others (Bulletin, November 1980, p. 173) regarding the shortage of manpower and poor recruitment to the specialty of mental handicap and their recommendation of joint appointments in psychiatry and mental handicap.

Mental handicap is considered to be a sub-specialty of psychiatry where psychiatric practice is limited to a special group of people who happen to be mentally handicapped. As an analogy, one can cite the relationship of general medicine to geriatrics and paediatrics. Also mentally handicapped persons are probably more prone to mental illness. The impact of psychotic illness on the poorly organized and illdeveloped personalities of the mentally handicapped results in symptoms which may confuse clinical diagnosis (Hucker et al, 1979. Psychiatric Illness and Mental Handicap, p. 32).

I think that many psychiatrists would be eager to take up this challenge and would be more interested in working with the mentally handicapped if the standard of treatment in mental handicap were more satisfactory; as it is the response is bound to be poor.

Considering the country's financial position, I do not think that change towards an improved standard will occur in the near future. Meanwhile joint appointments would provide an alternative.

\section{Brockhall Hospital}

UTPAL J. DeY

Blackburn, BB6 8AZ

\section{Approval under Section 28 (2)}

\section{Dear Sir,}

I have sympathy for Dr Hutchinson's views (Bulletin, November 1980 , p. 172) about the approval of medical practitioners under Section 28 (2) of the Mental Health Act 1959. My recent experience of the relevant administrative machinery has given me cause for concern.

Earlier this year I was appointed to the post of senior registrar in psychological medicine at this teaching hospital. 
I had a satisfactory training in psychiatry at a well-known psychiatric postgraduate establishment and I held the MRCPsych. Shortly after my appointment I applied for approval under Section 28 (2), only to be told six weeks later that my application had been rejected without reason given. However, I was asked to reapply immediately and this time after a short delay I learnt that my luck was in.

My reason for writing to you is to highlight what seems to me to be an arbitrary process, and one which is open to the sorts of abuse to which Dr Hutchinson has drawn attention.

Gregor Wilkinson

King's College Hospital

London, SES 9RS

\section{News Items}

\section{Examples of Medical Audit-2}

We talk about 'informed consent' and ask patients to sign forms implying they agree to have ECT (or anaesthetics or surgery). But do they really know what they are doing? Workers at the University of Pittsburgh conducted a 13 month study of 57 patients (out of a total of 82 for whom ECT was proposed in that time) to assess their understanding of the nature, risks and potential benefits of the treatment after it had supposedly been discussed with them by their doctor. This was done in two ways. At the time they signed consent they were given an easily read 15-item questionnaire to answer over the next two days with or without help, and later a 50-minute taped interview assessing both mental state and answers to specific questions about consent and the 15-item questionnaire (see Psychiatric News, 18 July 1980, pp 1, 11, 30). A few could not list correctly any of the risks, and 20 per cent said they did not know how to stop or withdraw from treatment once it had started. About 1 in 4 of the patients was judged to be incapable through illness of making a balanced rational decision for or against treatment, but it was noted that those who refused fonsent had less knowledge and understanding of the treatment than those who accepted. "The problem of informed consent ... is a fundamental problem (of) effectiveness of human communications.'

\section{Senior Psychicutrists needed in Australia}

The University of Newcastle, New South Wales, is currently involved in developing psychiatric services within the Hunter Region, and providing both undergraduate and postgraduate teaching in psychiatry with the Newcastle Medical

\section{Contributions requested}

Dear Sir,

Faculty News, the newspaper of North and West London Faculty of the Royal College of General Practitioners, would welcome news items as well as short articles and letters from GPs and specialists in other disciplines.

Contributions should be sent to the Editor, Dr B.A. Qureshi, 32 Legrace Avenue, Hounslow West, Middlesex TW4 7RS.

Bashir QuREshi

Middlesex, TW4 7RS

School and the Royal Australian and New Zealand College of Psychiatrists. One problem has been the difficulty in recruiting adequate senior clinical staff for one of the major psychiatric hospitals within the Region. This hospital is sited on the shores of Lake Macquarie and though somewhat isolated is now beginning to open up. The principal work at the hospital would involve supervising and training psychiatric trainees.

Any senior psychiatrist who, possibly at the time of retirement, might be interested in spending 6 or 12 months working in Australia is welcome to write to Beverley Raphael, Professor of Psychiatry, The University of Newcastle, New South Wales 2308, Australia.

\section{Exchange of Professional Position}

Dr Gerard Mallon, Head of Department of St Martha's Hospital at Antigonish, Nova Scotia, is interested in contacting a British psychiatrist who may wish to consider an exchange of professional positions for one year. The most simple arrangement would be to exchange both jobs and homes. Ideally the time of exchange would include the school year.

The Department of Psychiatry at St Martha's Hospital is mainly an out-patient and in-patient consultation service. Clinical staff consist of two psychiatrists, two social workers, two psychologists and one clinical nursing specialist. Dr Mallon is interested in a locum consultative post in the NHS.

Anyone interested should contact $\mathrm{Dr}$ Mallon at the Department of Psychiatry, St Martha's Hospital, PO Box 1417, Antigonish, NS, B2G 2 L7. 